\title{
Detectability of gear damage in combustion engines through a vibroacoustic method
}

\begin{abstract}
The paper presents a new methodology in vibroacoustic diagnostics of internal combustion engines during a cold test on the production line. This method utilizes order analysis of harmonic components of vibroacoustic signals taken from a combustion engine driven with an electric motor to identify the source of noise and vibration amplitude. The presented analysis of the harmonic orders was used to diagnose the damage of the gear teeth.
\end{abstract}

Key words: vibroacoustics, cold test, gears, order analysis

\section{Wykrywalność uszkodzeń przekładni zębatej silników spalinowych metodami wibroakustycznymi}

\author{
W artykule przedstawiono nowa metodyke wibroakustycznej diagnostyki silnika spalinowego podczas testu zimnego \\ na linii produkcyjnej. Wykorzystuje ona analize rzędowa składowych harmonicznych sygnatu wibroakustycznego silnika \\ spalinowego napędzanego silnikiem elektrycznym do identyfikacji źródła hatasu i amplitudy drgań. Zaprezentowaną analize \\ rzędów harmonicznych stosowano do diagnostyki uszkodzeń zębów koła zębatego przekładni silnika spalinowego. \\ Słowa kluczowe: wibroakustyka, test zimny, koła zębate, analiza rzędów składowych harmonicznych
}

\section{Introduction}

Diagnostics of automotive engines already begins in the production stage of the vehicles and is continually used in their operation $[4,5,10,12]$. It is because quality, material and workmanship shortcomings in the production process may facilitate the occurrence of damage during operation leading to premature wear, excessive noise and increased fuel consumption.

Because of large quantities of manufactured engines, a cold test is most frequently performed in the production process where the combustion engine is driven by an electric motor. During the test, the operation of all engine components is tested along with the intake and exhaust parameters, engine fluids pressure and correct assembly [4]. To assess the correctness of operation of the entire engine, vibroacoustic sensors are used whose signals, upon processing in dedicated software, are used to evaluate the noise level, correct operation of individual mechanical systems or detect faulty engine parts or assembly defects $[1,6,7,9,13]$.

Vibroacoustic signals have long been used to assess the condition of gear sets $[1,2,3]$. Experience gained in diagnosing gear sets allows identifying defective engine parts such as gears, camshafts balance shafts, etc.

It is noteworthy that modern combustion engines use gear sets to drive basic engine subassemblies as well as additional advanced systems such as balance shafts that counterbalance the forces of the second order. When toothed gears are manufactured, transported or finally fitted, a variety of anomalies may occur (faulty workmanship, mechanical damage or bad fitting). This results in defective engagement of the wheels which results in excessive noise, increased engine vibration amplitude and, consequently, premature wear of the parts. It is thus very important to eliminate defective parts at the stage of assembly or during the acceptance trials at the end of the assembly line. For the realization of this work, vibroacoustic

\section{Wstęp}

Diagnozowanie silników samochodowych rozpoczyna się już podczas produkcji samochodów i jest w sposób ciągły wykorzystywane w czasie ich eksploatacji [4, 5, 10, 12]. Wynika to z tego, że wszystkie braki jakościowe, materiałowe oraz montażowe w procesie produkcji mogą przyczynić się do wystąpienia uszkodzeń podczas eksploatacji, powodujących przyspieszone zużycie części, nadmierny hałas silnika oraz zwiększone zużycie paliwa.

Z uwagi na wielkoseryjność produkcji silników spalinowych, obecnie najczęściej w procesie produkcyjnym dokonywana jest kontrola silnika podczas tzw. testu zimnego, w którym silnik spalinowy napędzany jest silnikiem elektrycznym. W trakcie testu bada się działanie podstawowych układów silnika, parametry zasilania i wylotu, ciśnienia płynów silnikowych oraz poprawność montażu [4]. Do oceny prawidłowości działania całego silnika wykorzystuje się m.in. czujniki wibroakustyczne, których sygnały po obróbce w odpowiednich programach służą do oceny hałaśliwości całego silnika, oceny poprawności pracy układów mechanicznych czy też znalezienia wadliwych części silnika lub wad montażowych $[1,6,7,9,13]$.

Sygnały wibroakustyczne od dawna wykorzystywane są do oceny przekładni zębatych $[1,2,3]$. Doświadczenia uzyskane z diagnostyki przekładni zębatych pozwalają również na rozpoznanie wadliwości części silnika spalinowego, takich jak koła zębate, wałki rozrządu, wałki wyrównoważające $\mathrm{i}$ inne.

Należy zaznaczyć, że we współczesnych silnikach spalinowych wykorzystuje się przekładnie zębate zarówno do napędu podstawowych układów silnika, jak i dodatkowych, wynikających z rozwoju technologii silnikowych, przykładowo - wałków wyrównoważających siły drugiego rzędu. Podczas wytwarzania kół zębatych, ich transportu oraz ostatecznego montażu mogą wystąpić różne anomalie, tj. 
methods for the engine diagnostics in the cold test were used in the final assembly process.

\section{The research object}

The object of the investigations was a gear set transferring the power from the crankshaft to the balance shaft in a modern combustion engine (Fig. 1). During the experiment,

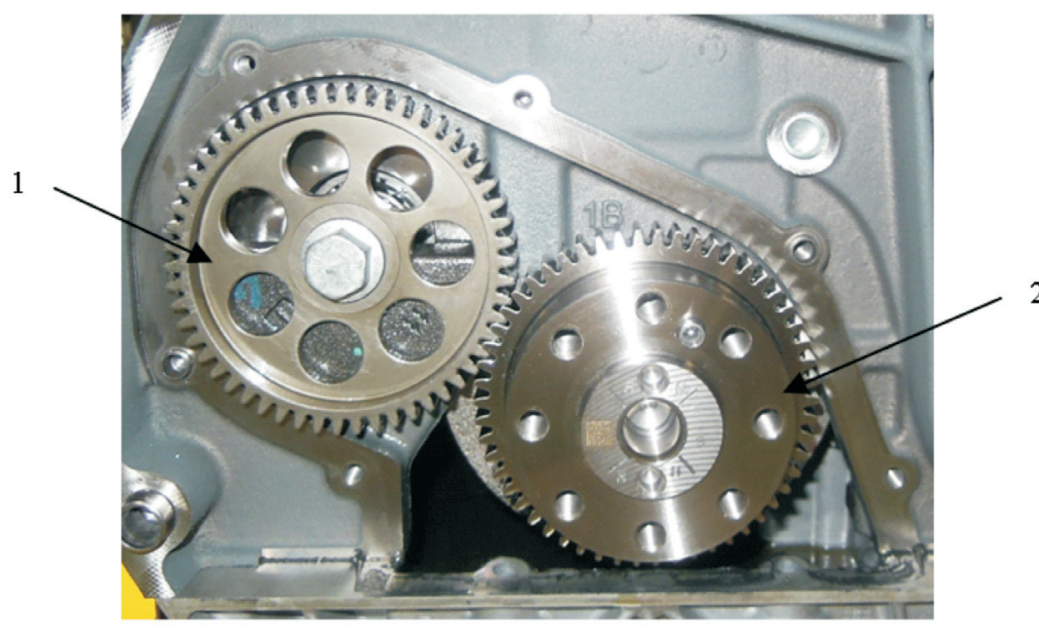

Fig. 1. Gear set of the ratio of 1:1 fitted in a spark ignition engine: 1 - toothed wheel of the balance shaft, 2 - crankshaft with a toothed flange

Rys. 1. Przektadnia zębata o przełożeniu 1:1 silnika samochodowego o zapłonie iskrowym: 1 - koło zębate wałka wyrównoważajacego, 2 - wat korbowy z wieńcem zębatym

some sections of the passive toothed wheel of the balance shaft were intentionally damaged in order to determine the criteria and most reliable method of defective element separation.

The investigations were performed on the engine assembly line according to cold test procedures prescribed by the manufacturer. The engine vibroacoustic tests relied on piezoelectric sensors by PCB Piezotronics fitted in the engine body [12].

\section{Analysis of the gear set operating conditions}

The conditions for proper engagement of the wheel teeth have been shown in Fig. 2:

- the motion transferred from the active wheel to the passive wheel is realized evenly, i.e. the contact of the teeth is not interrupted (teeth remain engaged) [8, 11],
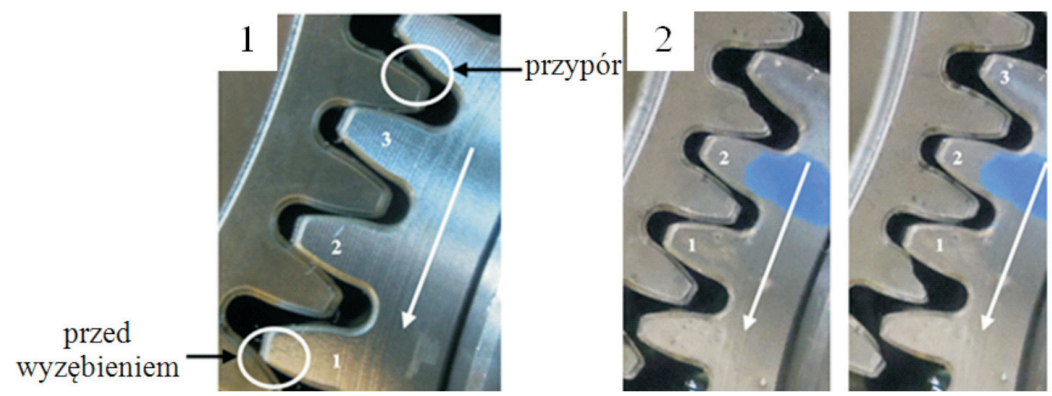

wadliwe wykonanie, uszkodzenie mechaniczne oraz wadliwy montaż. Powodują one nieprawidłową współpracę kół objawiającą się nadmiernym hałasem, zwiększoną amplitudą drgań silnika oraz w konsekwencji przyspieszonym zużyciem części. $Z$ tego powodu ważna jest eliminacja wadliwych części na etapie montażu lub w trakcie prób odbiorczych produktu na końcu linii montażowej. Do realizacji niniejszej pracy wykorzystano metody wibroakustyczne do diagnostyki silników samochodowych podczas testu zimnego w trakcie końcowego procesu montażowego.

\section{Obiekt badań}

Obiektem badań była przekładnia zębata przenosząca napęd z wału korbowego na wałek wyrównoważający, nowoczesnego samochodowego silnika spalinowego o zapłonie iskrowym (rys. 1). Podczas eksperymentu dokonywano celowych uszkodzeń mechanicznych zębów biernego koła zębatego wałka wyrównoważającego w celu określenia kryteriów i najbardziej niezawodnej metody separacji braków.

Badania przeprowadzano w warunkach linii montażowej obecnie produkowanego silnika zgodnie z procedurami określonymi przez producenta dla testu zimnego. Podczas testów wibroakustycznych silników wykorzystywano czujniki piezoelektryczne firmy PCB Piezotronics, umieszczone na korpusie [12].

\section{Analiza warunków pracy przekładni}

Warunki prawidłowej współpracy uzębień kół zębatych przedstawiono na rys. 2:

- ruch koła czynnego na bierne jest przenoszony równomiernie, czyli gdy przez cały czas trwania cyklu współpracy pary zębów występuje nieprzerwany styk zębów (przypór) $[8,11]$,

- przed wyzębieniem się jednej pary zębów następna para jest w przyporze [8],

- przełożenie jest niezmienne w czasie współpracy każdej pary zębów, a zatem gdy stosunek prędkości kątowych jest stały $[1,8,11]$.

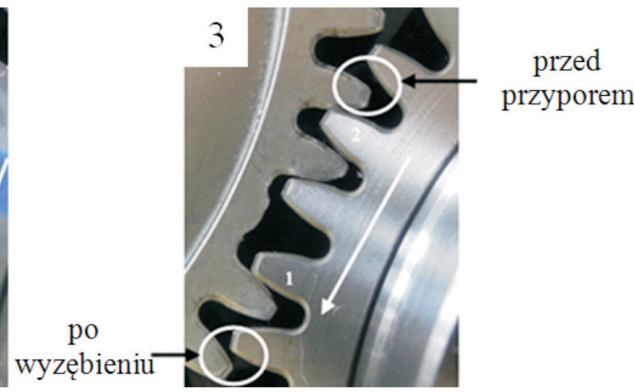

Fig. 2. Teeth contact: 1 - proper engagement of the teeth, 2 - chipped tooth, no contact between the teeth, 3 - missing tooth, no contact between the teeth Rys. 2. Schemat wspótpracy zazębienia: 1 - prawidłowa wspótpraca zazębienia, 2 -ząb uszkodzony, przerwany styk zębów, 3 - brak zęba, brak styku zębów

(wyzębienie - disengagement, przypór - engagement) 
- before disengaging one pair of teeth, the next pair is already engaged [8],

- the gear ratio is constant when the pairs of teeth engage, hence the angular velocity ratio is constant $[1,8,11]$.

In the investigations, the authors analyzed the results of measurements of the engine body vibrations for the following data:

- data from the entire range of harmonic components $(0-200$ Ord) [12],

- maximum and average values of vibrations in the ranges of 10 harmonic orders (division into 20 classes),

- individual harmonic orders (basic orders: 54, 108 and 162 and the orders for new operating conditions-wheels with teeth removed),

- image orders (e.g. 54 \pm 1 ).

During the vibroacoustic diagnostics, the frequencies are correlated with their corresponding sources e.g. engine speed with engagement of the teeth in the gear sets. It is usually possible to identify the first and the second harmonic originating in the basic vibrations generated following periodical vibrations whose course is not ideally sinusoidal.

Based on earlier analyses of vibroacoustic signals, the authors observed that around the frequency of the tooth engagement and its harmonics, image frequencies are generated caused by periodical changes. The image frequency bands appear at the engagement frequencies $\left(f_{z}\right)( \pm$ the frequency of the gear set rotation $\left(f_{p}\right)$ ), for the harmonic of the gear set rotation $\left(2 f_{p}\right)$ and farther as well as for the harmonics of the tooth engagement $\left(2 f_{z}\right)$ etc. [9].

The frequencies of the image bands can be notated as follows:

$$
\begin{aligned}
& \mathrm{f}_{\mathrm{z}} \pm \mathrm{f}_{\mathrm{p}} \quad \mathrm{f}_{\mathrm{z}} \pm 2 \mathrm{f}_{\mathrm{p}} \quad \mathrm{f}_{\mathrm{z}} \pm 3 \mathrm{f}_{\mathrm{p}} \\
& \mathrm{f}_{\mathrm{z}} \pm \mathrm{f}_{\mathrm{p}} \quad 2 \mathrm{f}_{\mathrm{z}} \pm \mathrm{f}_{\mathrm{p}} \quad 3 \mathrm{f}_{\mathrm{z}} \pm \mathrm{f}_{\mathrm{p}}
\end{aligned}
$$

Below, an example calculation has been presented of the frequency of a gear set of $z=54$ operating at the speed of $n$ $=1000 \mathrm{rpm}$ (Fig. 3):

$$
\begin{array}{ll}
\mathrm{f}_{\mathrm{p}}=\mathrm{n} / 60, & \mathrm{f}_{\mathrm{p}}=16.7 \mathrm{~Hz} \\
\mathrm{f}_{\mathrm{z}}=\mathrm{f}_{\mathrm{p}} \cdot \mathrm{z} & \mathrm{f}_{\mathrm{z}}=900 \mathrm{~Hz}
\end{array}
$$

Table 1. Change of the image frequencies into image orders (variable teeth engagement frequencies)

Tabela 1. Zamiana częstotliwości lustrzanych na rzędy lustrzane (zmienne częstotliwości zazębień)

\begin{tabular}{|c|c|c|}
\hline $\begin{array}{c}\text { Rotational speed/ } \\
\text { prędkość obrotowa } \\
{[\mathrm{rpm}]}\end{array}$ & $\begin{array}{c}\text { Image frequency/ } \\
\text { częstotliwość lustrza- } \\
n a[\mathrm{~Hz}]\end{array}$ & $\begin{array}{c}\text { Image orders/rzędy } \\
\text { lustrzane [Ord] }\end{array}$ \\
\hline 1000 & $900 \pm 16.7$ & $54 \pm 1$ \\
\hline 1500 & $1350 \pm 25$ & $54 \pm 1$ \\
\hline 2000 & $1800 \pm 33.3$ & $54 \pm 1$ \\
\hline 2500 & $2250 \pm 41.7$ & $54 \pm 1$ \\
\hline 3000 & $2700 \pm 50$ & $54 \pm 1$ \\
\hline
\end{tabular}

W badaniach analizowano wyniki pomiarów drgań korpusu dla następujących danych:

- z całego zakresu rzędów składowych harmonicznych (0-200 Ord) [12],

- maksymalnych i średnich wartości drgań w przedziałach po 10 rzędów harmonicznych (podział na 20 tzw. klas),

- pojedynczych rzędów harmonicznych (rzędy podstawowe:

54, 108 i 162 oraz rzędy dla nowych warunków pracy koła bez zębów),

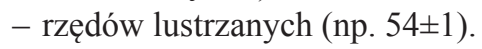

Podczas diagnostyki wibroakustycznej częstotliwości korelowane są z odpowiadającymi im źródłami pochodzenia, np. z prędkością obrotową wału korbowego oraz z zazębianiem się par kół zębatych. Warto zaznaczyć, że prawie zawsze można zidentyfikować również pierwsze i drugie harmoniczne pochodzące od drgań podstawowych, powstałych w wyniku drgań okresowych, których przebieg nie jest idealnie sinusoidalny.

W wyniku wcześniejszych analiz sygnałów wibroakustycznych stwierdzono, że wokół częstotliwości „zazębienia" i jej harmonicznych powstają również częstotliwości lustrzane, spowodowane zmianami okresowymi. Pasma lustrzane pojawiają się przy częstotliwościach zazębień $\left(\mathrm{f}_{\mathrm{z}}\right) \pm$ częstotliwość obrotu przekładni $\left(\mathrm{f}_{\mathrm{p}}\right)$, jak również dla harmonicznych obrotu przekładni $\left(2 \mathrm{f}_{\mathrm{p}}\right) \mathrm{i}$ dalszych oraz dla harmonicznych zazębień $(2 \mathrm{f})$ itd. [9].

Częstotliwości pasm lustrzanych możemy zapisać w postaci (1) i (2).

Poniżej przedstawiono przykładowe obliczenie częstotliwości przekładni zębatej o liczbie zębów $\mathrm{z}=54$ pracującej $\mathrm{z}$ prędkością obrotową $\mathrm{n}=1000 \mathrm{obr} / \mathrm{min}$ (rys. 3), wzory (3) i (4).

W tabelach 1 i 2 podano częstotliwości oraz rzędy lustrzane wyliczone z wzorów (1) i (2), które były analizowane w czasie badań diagnostyki przekładni.

\section{Opis eksperymentu}

Celem eksperymentu była próba klasyfikacji rodzaju i stopnia uszkodzeń zębów kół przekładni, w wyniku zmian warunków prawidłowej współpracy uzębień kół zębatych, wykorzystująca do tego celu analizę rzędów (ang. Order Analysis), czyli analizę synchroniczną [12].

Dokonano czterech typów uszkodzeń mechanicznych zębów koła: uszkodzenie jednego zęba, usunięcie jednego zęba, usunięcie czterech zębów oraz uszkodzenie powierzchni wszystkich zębów wykonane szlifierką kątową.

Table 2. Change of the image frequencies into image orders (variable frequencies of the gear set rotation)

Tabela 2. Zamiana częstotliwości lustrzanych na rzędy lustrzane (zmienne częstotliwości obrotu przektadni)

\begin{tabular}{|c|c|c|}
\hline $\begin{array}{c}\text { Rotational speed/ } \\
\text { prędkość obrotowa } \\
{[\mathrm{rpm}]}\end{array}$ & $\begin{array}{c}\text { Image frequency/czę- } \\
\text { stotliwość lustrzana } \\
{[\mathrm{Hz}]}\end{array}$ & $\begin{array}{c}\text { Image orders/rzeddy } \\
\text { lustrzane [Ord] }\end{array}$ \\
\hline 1000 & $900 \pm 16.7$ & $54 \pm 1$ \\
\hline 1000 & $900 \pm 33.3$ & $54 \pm 2$ \\
\hline 1000 & $900 \pm 50.0$ & $54 \pm 3$ \\
\hline
\end{tabular}


In Tables 1 and 2 frequencies and image orders have been given calculated from formulas (1) and (2), that were analyzed during the diagnostic tests of the gear set.

\section{Description of the experiment}

The aim of the experiment was an attempt to classify the type and extent of damage of the wheel teeth (resulting from the changes of the conditions of proper wheel engagement) through order analysis i.e. synchronous analysis [12].

Four types of mechanical damage of the wheel teeth were performed: chipping of a single tooth, removing a single tooth, removal of four teeth and damaging of the surface of all teeth with a disc grinder.

\subsection{Toothed wheel with a chipped tooth}

The wheel with the chipped tooth has been shown in Fig. 4 and the vibroacoustic signal in Fig. 5 (yellow denotes the damaged wheel).
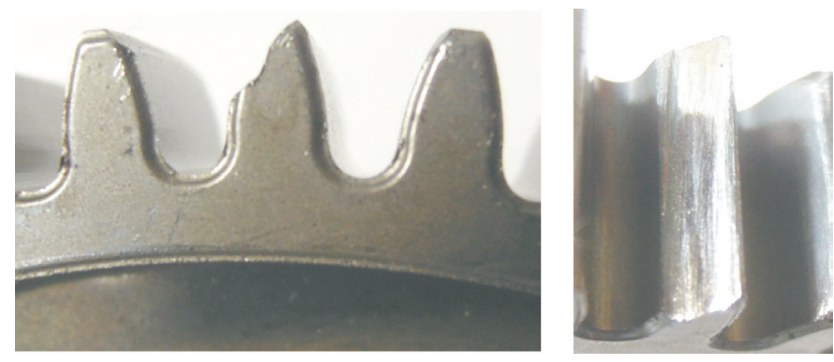

Fig. 4. Chipped tooth of the wheel of the balance shaft

Rys. 4. Koło zębate wałka wyrównoważającego z uszkodzonym zębem

\subsection{Toothed wheel with a single tooth removed}

The wheel with the tooth removed has been shown in Fig. 6 and the vibroacoustic signal against 100 trials of good engines in Fig. 7.

\subsection{Toothed wheel with four teeth removed evenly on}

\section{the circumference}

The wheel with four teeth removed has been shown in Fig. 8 and the vibroacoustic signal in Fig. 9. The teeth were removed symmetrically on the circumference every circa $90^{\circ}$.

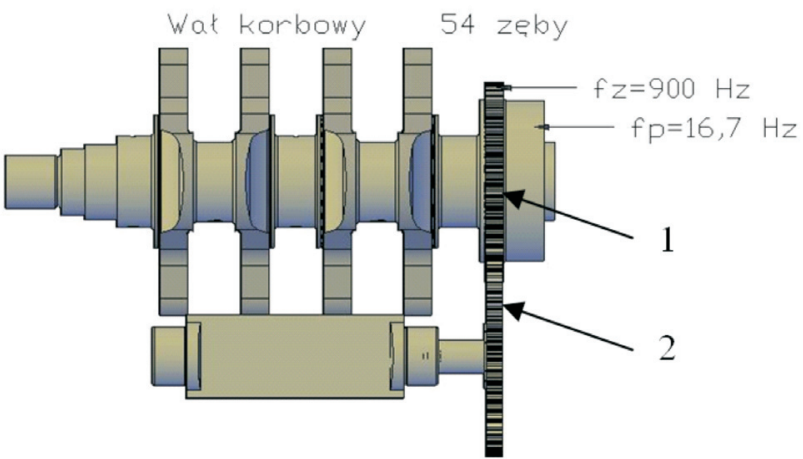

Fig. 3. Schematics of the gear set of the ratio of $1: 1$ used in the tested engine: 1 - crankshaft with a toothed flange, 2 - toothed wheel of the balance shaft

Rys. 3. Schemat przekładni zębatej o przełożeniu 1:1stosowanej w badanym silniku: 1 -wat korbowy z wieńcem zębatym, 2 - koło zębate watka

wyrównoważającego (wat korbowy-crankshaft, zęby - teeth)

\subsection{Koło zębate $\mathrm{z}$ uszkodzonym zębem}

Koło z uszkodzonym zębem przedstawiono na rys. 4, a sygnał wibroakustyczny na rys. 5 (kolorem żółtym oznaczono sygnał koła uszkodzonego).

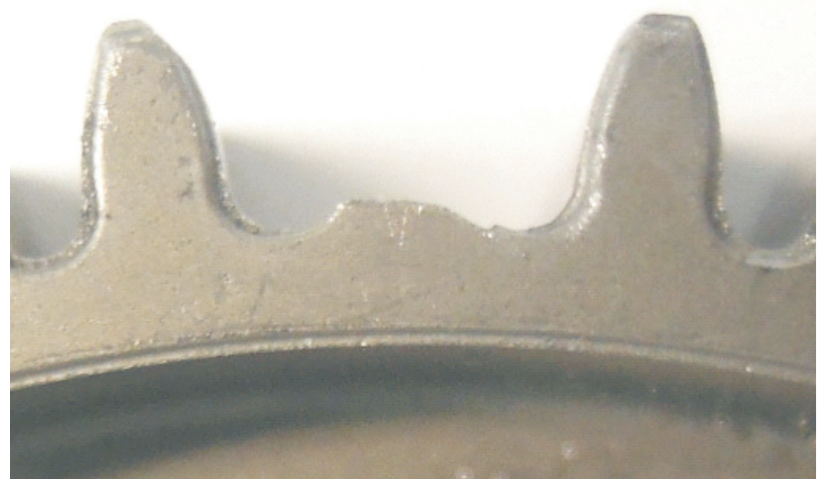

Fig. 6. Damaged toothed wheel of the balance shaft (single tooth removed)

Rys. 6. Koło zębate watka wyrównoważającego z wyłamanym zębem

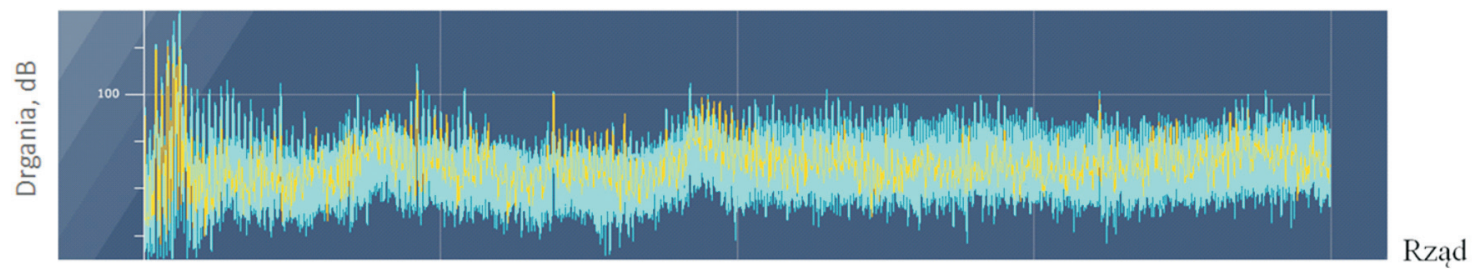

Fig. 5. Vibrations of the engine body (chipped tooth of the wheel, yellow color) against 100 trials of good engines

Rys. 5. Drgania korpusu silnika z uszkodzonym zębem (kolor żólty) na tle 100 prób silników prawidłowych (drgania-vibrations, rząd-order)

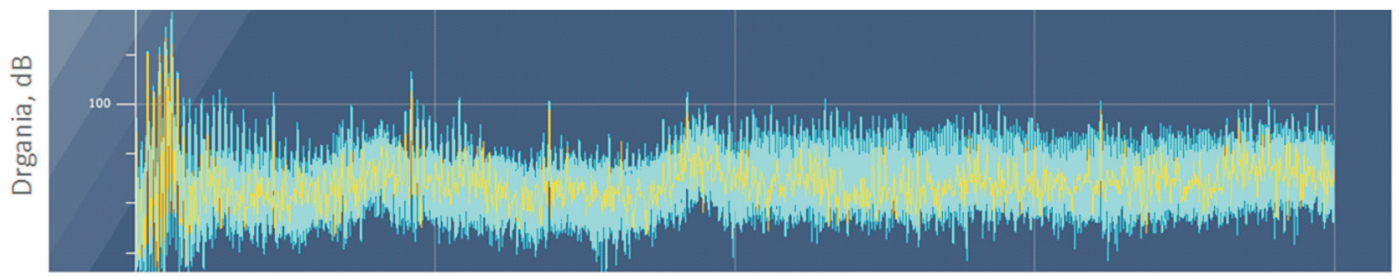

Fig. 7. Vibrations of the engine body (damaged wheel with a single tooth removed, yellow color) against 100 trials of good engines Rys. 7. Drgania korpusu silnika z wyłamanym zębem (kolor żólty) na tle 100 prób silników prawidłowych (drgania - vibrations, rząd-order) 


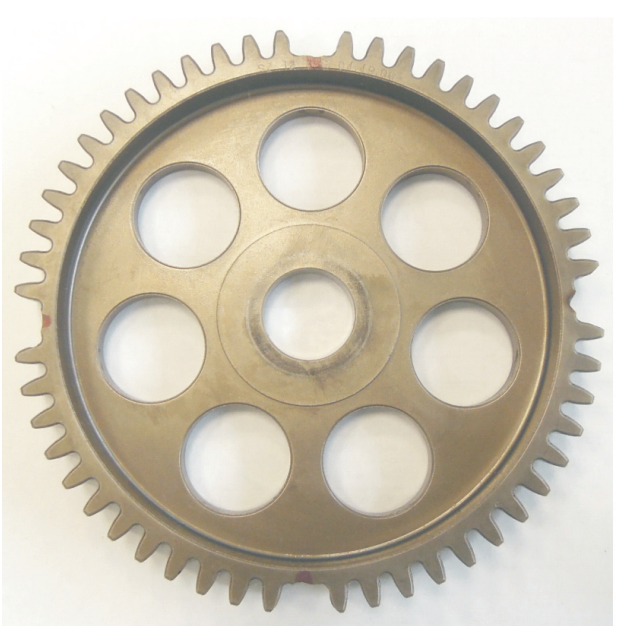

Fig. 8. Toothed wheel of the balance shaft with four teeth removed Rys. 8. Koło zębate wałka wyrównoważającego bez czterech zębów

\subsection{Koło zębate $\mathrm{z}$ wyłamanym zębem}

Koło z wyłamanym zębem przedstawiono na rys. 6, a sygnał wibroakustyczny na tle sygnałów 100 silników zakwalifikowanych jako prawidłowe na rys. 7 .

\subsection{Koło zębate bez czterech zębów wyłamanych rów- nomiernie na obwodzie}

Koło z brakiem czterech zębów przedstawiono na rys. 8, a sygnał wibroakustyczny na rys. 9. Zęby usunięto symetrycznie na obwodzie co ok. $90^{\circ}$.

\subsection{Koło zębate z uszkodzoną powierzchnią zębów za pomocą szlifierki kątowej}

Koło z uszkodzonymi powierzchniami zębów przedstawiono na rys. 10, a sygnał wibroakustyczny na rys. 11 .

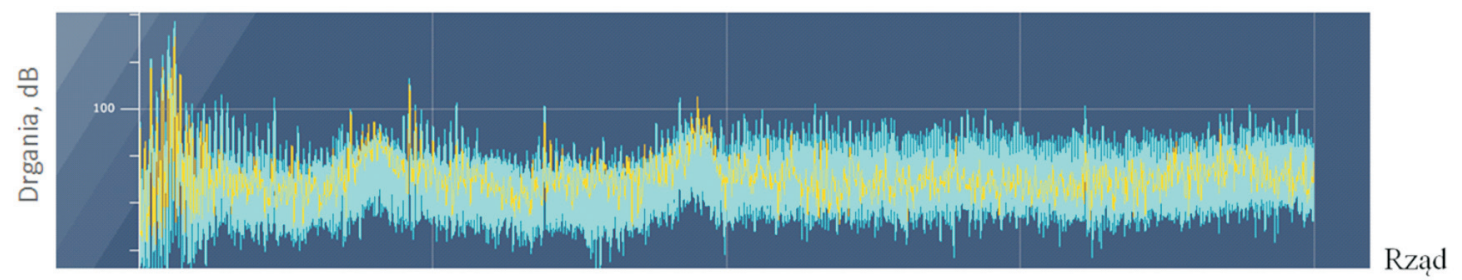

Fig. 9. Vibrations of the engine body (damaged wheel with four teeth removed, yellow color) against 100 trials of good engines Rys. 9. Drgania korpusu silnika z kołem bez czterech zębów (kolor żółty) na tle 100 prób silników prawidłowych (drgania - vibrations, rząd - order)

\subsection{Toothed wheel damaged with a disc grinder}

The wheel with the teeth surface damaged has been shown in Fig. 10 and the vibroacoustic signal in Fig. 11.

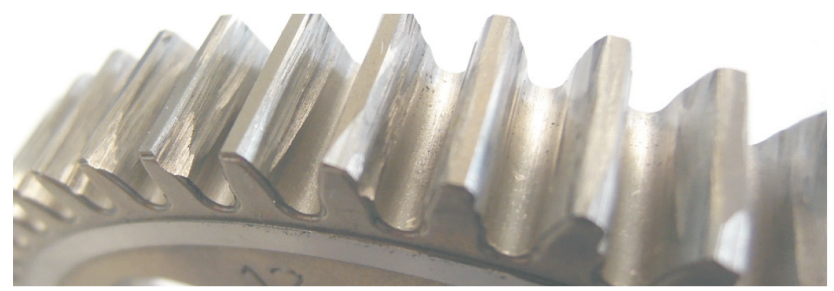

Fig. 10. Toothed wheel with the teeth surface mechanically damaged with a disc grinder

Rys. 10. Koło zębate z powierzchnią zębów uszkodzonych mechanicznie szlifierka kątowa

\section{Analysis of the results}

\subsection{The limits curve (the entire range of harmonic components)}

The measurement covered the entire harmonic range from 0 to 200 Ord (Fig. 12) and the determined percent value denotes part of the curve above the earlier set limits curve (a rule was applied that $0 \%$ denotes the entire curve below the limits curve and $100 \%$ - the entire curve is above the limits curve).

The values of the vibrations for the entire interval of the harmonic orders (0-200 Ord) exceeding the limits curve are as follows (Fig. 12):

- wheel with a chipped tooth $-7.64 \%$,

- wheel with a single tooth removed $-4.38 \%$,

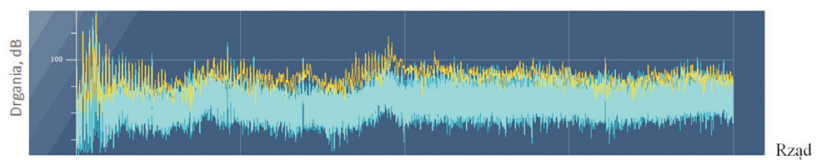

Fig. 11. Vibrations of the engine body (teeth damaged with a disc grinder, yellow color) against 100 trials of good engines

Rys. 11. Drgania korpusu silnika z kołem o uszkodzonej powierzchni zębów (kolor żótty) na tle 100 prób silników kwalifikowanych jako prawidtowe (drgania - vibrations, rzad-order)

\section{Analiza wyników badań}

\subsection{Krzywa limitu (cały zakres rzędów składowych harmonicznych)}

Dokonany pomiar obejmuje zakres rzędów harmonicznych od 0 do 200 Ord (rys. 12), a określona wartość procentowa oznacza część krzywej powyżej ustalonej wcześniej krzywej limitu (stosowano przy tym zasadę, że 0\% oznacza, iż cała krzywa drgań znajduje się pod krzywą limitów, 100\% - cała krzywa jest powyżej wyznaczonej krzywej limitów).

Wartości drgań dla całego przedziału rzędów harmonicznych (0-200 Ord) przekraczające krzywą limitów są następujące (rys. 12):

- koło z uszkodzonym zębem - 7,64\%,

- koło bez jednego zęba - 4,38\%,

- koło bez czterech zębów - 7,39\%,

- koło z uszkodzonymi zębami szlifierką kątową $66,77 \%$. 
- wheel with four teeth removed $-7.39 \%$,

- wheel with the teeth damaged with a disc grinder$66.77 \%$.

From the analysis it results that the engine vibrations (wheel damaged with a disc grinder) are much different from the rest, which is a consequence of serious damage of the surface of all teeth.

\subsection{Maximum values of the harmonic orders (division into classes)}

In the further part of the investigations, an analysis of the measurement was performed covering the range of harmonic orders from 0 to 200 Ord divided into twenty intervals, 10 orders each (classes). The result of the analysis was the maximum vibrations amplitude for a given interval (max) given in $\mathrm{dB}$. Figure 13 presents an example 1st, 5th and 10th interval.

The results for the maximum values in individual classes shown in Fig. 14 also present high values of vibrations for the teeth damaged with a disc grinder.

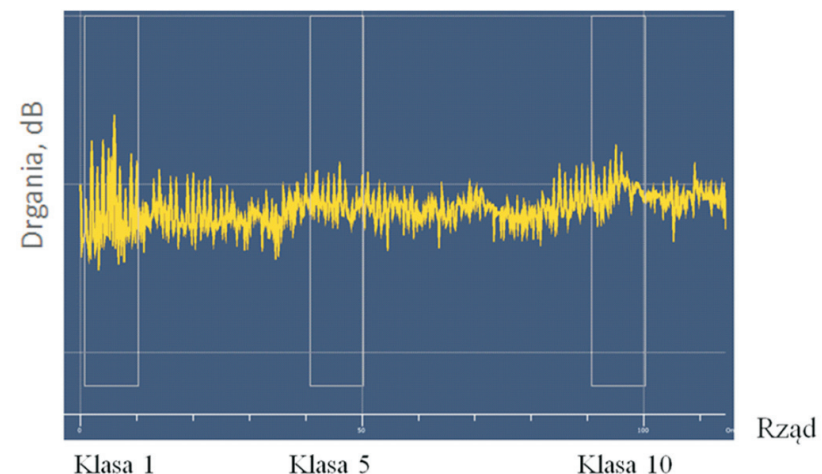

Fig. 13. Vibrations of the engine body-curve for the orders from the entire range ( $0-200$ Ord) for the wheel with the teeth damaged with a disc grinder

Rys. 13. Drgania korpusu - krzywa dla rzędów z całego zakresu (0-200 Ord) dla koła z zębami uszkodzonymi szlifierka kątowa (drgania - vibrations, rzad-order, klasa-class)

\subsection{Average values of harmonic orders (division into classes)}

The division of the entire range of harmonic orders from 0 to 200 Ord into twenty intervals, 10 orders each (classes) enables determining the average vibrations amplitude for a given interval in $\mathrm{dB}$. The results of the average vibrations value for the investigated cases of damage have been shown in Fig. 15.

The analysis of the average value for individual classes indicates an more distinct increase in the vibrations level for the investigated types of damage (Fig. 15).

\subsection{Analysis of individual components of harmonic orders}

The performed measurements covered individual components of harmonic orders selected in the interval 0-200 Ord (Fig. 16, example of measurements of order 54). The result was the value of the vibrations amplitude for a given harmonic order in $\mathrm{dB}$.
Z analizy wyników wynika, że drgania silnika z kołem uszkodzonym szlifierką kątową odbiegają znacznie od pozostałych, co jest konsekwencją znacznych uszkodzeń powierzchni wszystkich zębów.

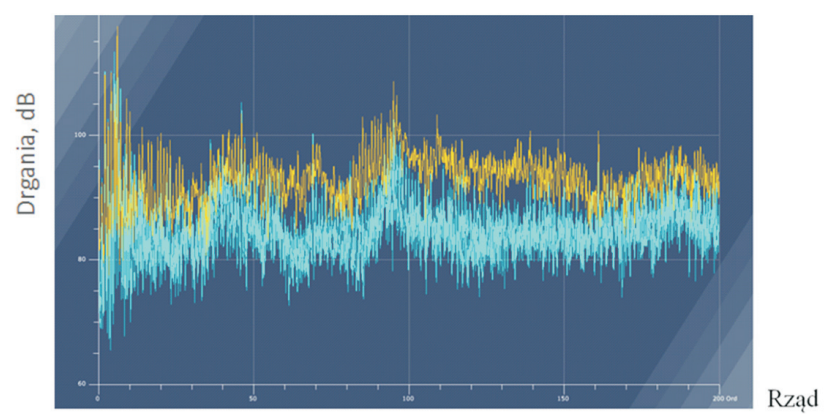

Fig. 12. Vibrations of the engine body-curve for the orders from the entire range (0-200 Ord) - yellow curve - for the wheel with the teeth damaged with a disc grinder, the limits curve are marked blue

Rys. 12. Drgania korpusu silnika - krzywa dla rzędów z catego zakresu (0-200 Ord): krzywa żółta - dla koła z uszkodzonymi zębami szlifierka kątowa, krzywa limitów - kolor niebieski (drgania - vibrations, rządorder)

\subsection{Maksymalne wartości rzędów harmonicznych (podział na klasy)}

W dalszej części badań wykonano analizę pomiaru obejmującego zakres rzędów harmonicznych od 0 do 200 Ord podzielonych na dwadzieścia przedziałów po 10 rzędów (tzw. klasy). Wynikiem analizy jest maksymalna wartość amplitudy drgań dla danego przedziału (max) w dB. Rysunek 13 przedstawia przykładowy przedział pierwszy, piąty i dziesiąty.

Wyniki dla maksymalnych wartości w poszczególnych klasach przedstawione na rys. 14 pokazują również wysokie wartości drgań dla zębów uszkodzonych szlifierką kątową.

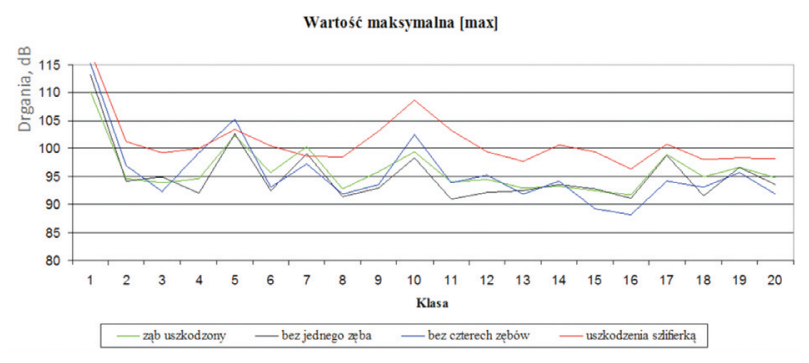

Fig. 14. Maximum values of the engine vibrations amplitude in individual classes

Rys. 14. Maksymalne wartości amplitudy drgań kadluba silnika w poszczególnych klasach (drgania - vibrations, wartość maksymalna-maximum value, ząb uszkodzony - chipped tooth, bez jednego zęba-single tooth removed, bez czterech zębów - four teeth removed, uszkodzenia szlifierka - damaged with a disc grinder)

\section{3. Średnie wartości rzędów harmonicznych (podział na klasy)}

Podział całego zakresu rzędów harmonicznych od 0 do 200 Ord na dwadzieścia przedziałów po 10 rzędów (klasy) umożliwia określenie średniej wartości amplitudy drgań dla danego przedziału w dB. Wyniki średniej wartości drgań dla badanych przypadków uszkodzeń przedstawiono na rys. 15 . 


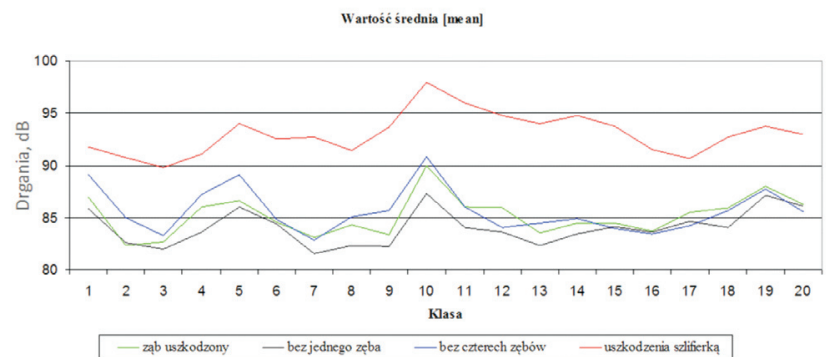

Fig. 15. Average values of engine vibrations amplitude in individual classes

Rys. 15. Wartości średnie amplitudy drgań kadluba silnika w poszczególnych klasach (drgania - vibrations, wartość średnia - average value, ząb uszkodzony - chipped tooth, bez jednego zęba - single tooth removed, bez czterech zębów - four teeth removed, uszkodzenia szlifierka - damaged with a disc grinder)

The analysis of the harmonic orders for wheel with the teeth removed

The toothed wheel that has all 54 teeth is controlled in the system by measuring the harmonic orders of the same value following the appearance of 54 signals of identical moment of generation during a single wheel rotation.

Because of the removal of one tooth, the wheel with 53 teeth cannot be controlled by measuring of the harmonic order of 53 because the signals are not periodical (missing tooth 54 whose presence would ensure periodicity). New orders must thus be found for the modified conditions that will maintain the periodicity of the signal. Figures 17 and 18 present the method of determining of new orders for the discussed case.

The wheel with four teeth removed, as per the schematics shown in Fig. 8 (signal: 12 teeth - tooth missing, 13 teeth - tooth missing, 12 teeth - tooth missing, 13 teeth - tooth missing) shows signals as presented in Fig. 17.

The wheel with a single tooth removed (53 teeth - one tooth missing) shows signals as presented in Fig. 18.

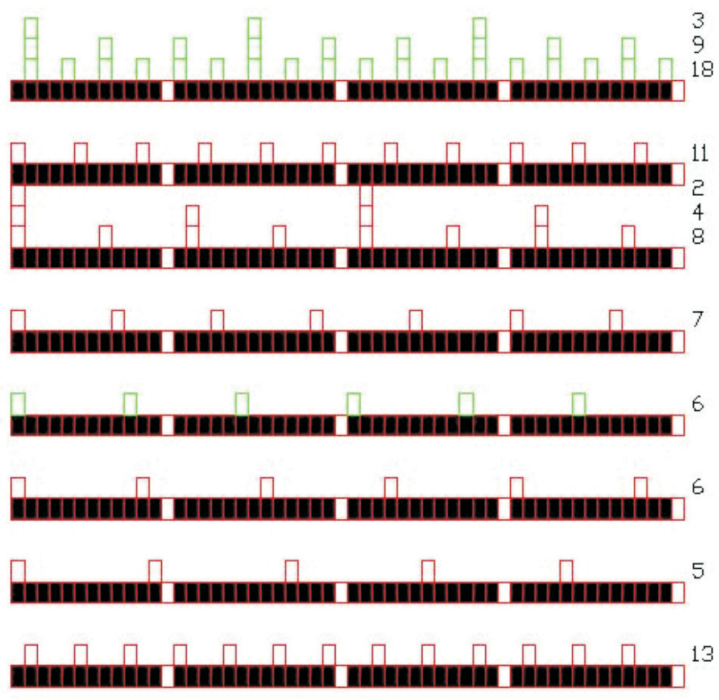

Fig. 17. Orders for the wheel with four teeth removed Rys. 17. Rzędy dla koła bez 4 zębów
Analiza średniej wartości dla poszczególnych klas wskazuje na wyraźniejszy wzrost drgań dla badanych uszkodzeń kół (rys. 15).

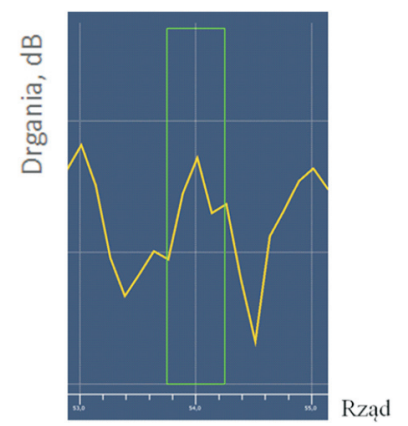

Fig. 16. Engine block vibrations - measurement of the harmonic orders 54 (green - limits window)

Rys. 16. Drgania kadtuba silnika - pomiar rzędu harmonicznego 54 (kolor zielony - okienko limitów) (drgania-vibrations, rząd-order)

\subsection{Analiza pojedynczych rzędów składowych harmo- nicznych}

Dokonane pomiary obejmują pojedyncze rzędy składowych harmonicznych wybrane w przedziale 0-200 Ord (rys. 16, przykład pomiaru rzędu numer 54). Wynikiem jest wartość amplitudy drgań dla danego rzędu harmonicznego $\mathrm{w} \mathrm{dB}$.

\section{Analiza rzędów harmonicznych dla kół z wyłamanymi zębami}

Koło zębate mające wszystkie 54 zęby kontrolowane jest w systemie przez pomiar rzędów harmonicznych o tej samej wartości w wyniku pojawiania się 54 sygnałów o jednakowym okresie powstawania podczas jednego obrotu koła.

W wyniku wyłamania jednego zęba koło o 53 zębach nie może być kontrolowane przez pomiar rzędu harmonicznego o wartości 53, ponieważ sygnały nie są okresowe (brak zęba 54., który zapewniałby okresowość). Należy zatem znaleźć nowe rzędy dla zmienionych warunków pracy, które zachowają okresowość sygnału. Na rysunkach 17 i 18 przedstawiono sposób ustalania nowych rzędów dla omawianego przypadku.

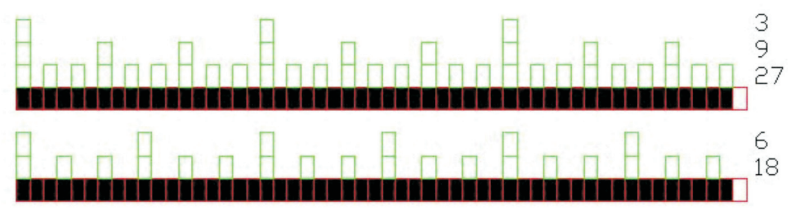

Fig. 18. Orders for the wheel with a single tooth removed (a fragment) Rys. 18. Rzędy dla koła bez 1 zęba (fragment)

Koło bez czterech zębów wg schematu pokazanego na rys. 8 (sygnał: 12 zębów-brak zęba, 13 zębów-brak zęba, 12 zębów-brak zęba, 13 zębów-brak zęba) wykazuje sygnały takie, jak pokazano na rys. 17.

Koło bez jednego zęba (53 zęby-brak zęba) wykazuje sygnały takie, jak pokazano na rys. 18 . 
At maximum, for the wheel with four teeth removed, instead of order 54 order 18 is obtained. Then, its two harmonics 36 and 54 are assumed and the missing order 36 is introduced in the test. The results have been shown in Table 3.

For the wheel with a single tooth removed instead of order 54 order 27 is obtained at maximum. Analogically, its two harmonics 54 and 81 are assumed and the missing order 81 is introduced in the test. The results have been presented in table 4.

For order 54 (tab. 5), the vibrations increase with the level of damage. According to the above presented analysis, for the new engagement conditions the vibrations are the effect of:

- a damaged tooth - basic order for 54 teeth,

- a single tooth removed - as per the above analysis of orders, I harmonic of order 27 ,

- with four teeth removed - as per the above analysis of orders, II harmonic of order 18,

- damage with a disc grinder - high vibrations amplitudes resulting from severe tooth damage.

\section{Image orders analysis}

Order 54

Vibrations around order 54 are correct for all cases of the wheel damage. The highest vibrations amplitude is obtained for order 54 and is gradually decreasing as the distance from this order increases $(54 \pm 1,54 \pm 2$ and $54 \pm 3)$ - Fig. 19.
Dla koła bez 4 zębów zamiast rzędu 54 uzyskuje się maksymalnie rząd 18, następnie przyjmuje się jego dwie harmoniczne 36 i 54 i wprowadza do testu brakujący rząd 36. Wyniki przedstawiono w tab. 3.

Dla koła bez jednego zęba zamiast rzędu 54 uzyskuje się maksymalnie rząd 27; analogicznie przyjmuje się jego dwie harmoniczne 54 i 81 i wprowadza do testu brakujący rząd 81 . Wyniki przedstawiono w tab. 4.

Dla rzędu 54 (tab. 5) wraz ze wzrostem stopnia uszkodzeń następuje również wzrost drgań. Według przedstawionej powyższej analizy dla nowych warunków współpracy drgania są efektem:

- ząb uszkodzony - rząd podstawowy dla 54 zębów,

- bez 1 zęba - wg powyższej analizy rzędów, I harmoniczna rzędu 27 ,

- bez 4 zębów - wg powyższej analizy rzędów, II harmoniczna rzędu 18 ,

- uszkodzenia szlifierką - wysokie amplitudy drgań w wyniku bardzo dużych uszkodzeń zębów.

\section{Analiza rzędów lustrzanych}

\section{Order 54}

Drgania wokół rzędu 54 zachowują się prawidłowo dla wszystkich przypadków uszkodzeń zębów koła przekładni silnika. Najwyższą amplitudę drgań uzyskano dla rzędu 54 i są one stopniowo malejące w miarę oddalania się od niego $(54 \pm 1,54 \pm 2$ i $54 \pm 3)$ - rys. 19 .

Table 3. Results of vibrations for special orders (toothed wheel with four teeth removed)

Tabela 3. Wyniki drgań dla rzędów specjalnych (koło zębate bez 4 zębów)

\begin{tabular}{|c|c|c|c|c|c|}
\hline Order/rząd & Unit/jednostka & $\begin{array}{c}\text { A damaged tooth/ząb } \\
\text { uszkodzony }\end{array}$ & $\begin{array}{c}\text { A single tooth re- } \\
\text { moved/brak jednego } \\
\text { zęba }\end{array}$ & $\begin{array}{c}\text { Four teeth removed/ } \\
\text { brak 4 zębów }\end{array}$ & $\begin{array}{c}\text { Teeth damaged with a disc } \\
\text { grinder/uszkodzenie zębów } \\
\text { szlifierka }\end{array}$ \\
\hline Order 018 & $\mathrm{dB}[-]$ & 92.27 & 86.141 & 87.375 & 91.226 \\
\hline Order 036 & $\mathrm{dB}[-]$ & 89.589 & 90.792 & 99.337 & 97.793 \\
\hline Order 054 & $\mathrm{~dB}[-]$ & 89.225 & 91.322 & 93.077 & 97.195 \\
\hline
\end{tabular}

Table 4. Results of vibrations for special orders (toothed wheel with a single tooth removed)

Tabela 4. Wyniki drgań dla rzędów specjalnych (koło zębate bez jednego zęba)

\begin{tabular}{|c|c|c|c|c|c|}
\hline Order/rzad & Unit/jednostka & $\begin{array}{c}\text { A damaged tooth/ząb } \\
\text { uszkodzony }\end{array}$ & $\begin{array}{c}\text { A single tooth re- } \\
\text { moved/brakjednego } \\
\text { zęba }\end{array}$ & $\begin{array}{c}\text { Four teeth re- } \\
\text { moved/brak } \\
4 \text { zębów }\end{array}$ & $\begin{array}{c}\text { Teeth damaged with a disc } \\
\text { grinder/uszkodzenie zębów } \\
\text { szlifierka }\end{array}$ \\
\hline Order 027 & $\mathrm{dB}[-]$ & 88.196 & 88.498 & 89.951 & 93.077 \\
\hline Order 054 & $\mathrm{dB}[-]$ & 89.225 & 91.322 & 95.302 & 97.195 \\
\hline Order 081 & $\mathrm{dB}[-]$ & 95.832 & 92.387 & 88.048 & 93.39 \\
\hline
\end{tabular}

Table 5. Vibrations results for basic orders

Tabela 5. Wyniki drgań dla rzędów podstawowych

\begin{tabular}{|c|c|c|c|c|c|}
\hline Order/rzad & Unit/jednostka & $\begin{array}{c}\text { A damaged tooth/ząb } \\
\text { uszkodzony }\end{array}$ & $\begin{array}{c}\text { A single tooth re- } \\
\text { moved/brakjednego } \\
\text { zęba }\end{array}$ & $\begin{array}{c}\text { Four teeth re- } \\
\text { moved/brak } \\
4 \text { zębów }\end{array}$ & $\begin{array}{c}\text { Teeth damaged with a disc } \\
\text { grinder/uszkodzenie zębów } \\
\text { szlifierka }\end{array}$ \\
\hline Order 054 & $\mathrm{dB}[-]$ & 89.225 & 91.322 & 93.077 & 96.648 \\
\hline Order 108 & $\mathrm{dB}[-]$ & 88.407 & 83.712 & 87.195 & 97.811 \\
\hline Order 162 & $\mathrm{dB}[-]$ & 83.304 & 86.793 & 91.128 \\
\hline
\end{tabular}




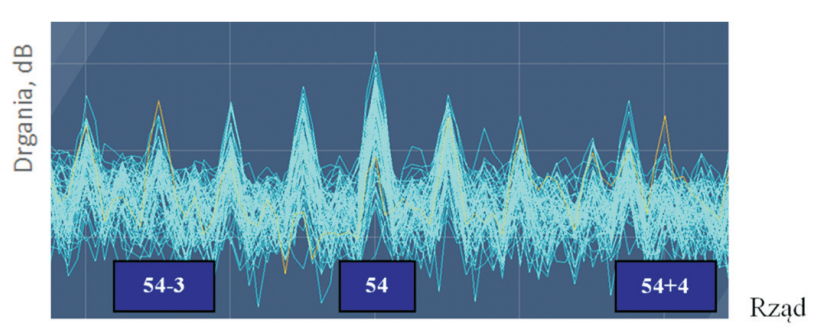

Fig. 19. Harmonic order 54 - chipped tooth

Rys. 19. Rząd harmoniczny 54 - uszkodzony ząb (drgania-vibrations, rzad-order)

Order 81

A very high amplitude level has been observed for order 81 (the wheel with the damaged tooth-yellow curve). The distortions around the image orders appear as the damage progresses - Figs. 20, 21.

\section{Order 36}

Similar changes occur for the wheel with four teeth removed and the one damaged with a discs grinder. The vibrations amplitudes increase with the level of damage on the right side of the image of order 36 (yellow curve). Order 33 also shows a high level of vibrations - Fig. 22.

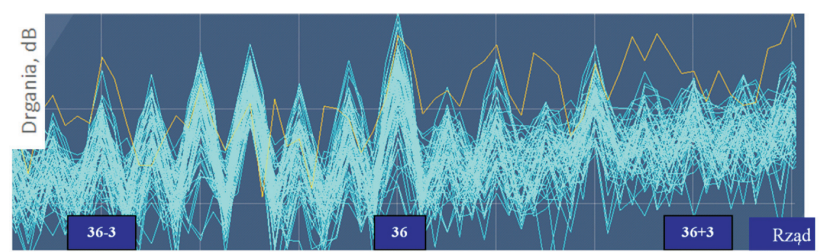

Fig. 22. Harmonic order 36 - teeth damaged with a disc grinder Rys. 22. Rząd harmoniczny 36 - zęby koła uszkodzone szlifierka kątowa (drgania-vibrations, rzad-order)

\section{Order 108}

Vibrations for the image harmonic orders to 108 Ord increase with the distance from the central harmonic order - Fig. 23.

\section{Order 162}

A lack of vibration symmetry around harmonic order 162 has been observed. Harmonic image orders are difficult to define because of high vibrations amplitude for order $161-$ Fig. 24.

\section{Order 27} 25 .

Vibrations around harmonic order 27 are correct - Fig.

\section{Conclusions}

1. The diagnostic efficiency of three analyzed vibration curves has been compared in the paper:

- the limits curve (entire range of orders of harmonic components);

- the curve of the maximum vibrations amplitude for a group of selected harmonic orders (division into classes);

- average values of the harmonic orders in a group (division into classes).

\section{Order 81}

Zaobserwowano bardzo wysoką wartość amplitudy drgań dla rzędu 81 (koło z uszkodzonym zębem - krzywa żółta). $\mathrm{W}$ miarę wzrostu uszkodzenia następuje pojawianie się zakłóceń wokół rzędów lustrzanych - rys. 20 i 21.

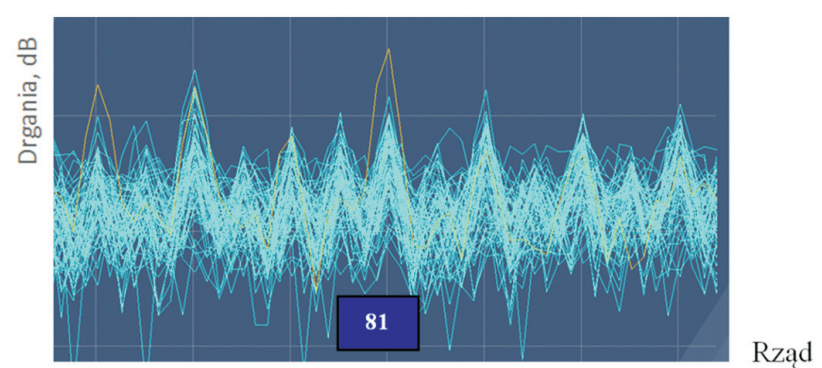

Fig. 20. Harmonic order 81 - wheel with the chipped tooth Rys. 20. Rząd harmoniczny 81 - koło z uszkodzonym zębem

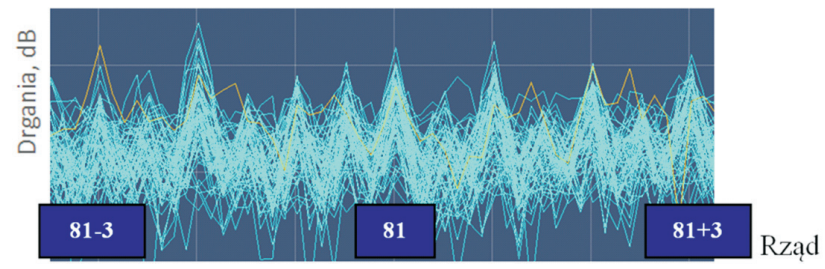

Fig. 21. Harmonic order 81 - wheel with four teeth removed Rys. 21. Rząd harmoniczny 81 - koło bez czterech zębów (drganiavibrations, rzad-order)

\section{Order 36}

Podobne zmiany występują dla koła bez 4. zębów oraz uszkodzonego szlifierką kątową. Wraz ze wzrostem uszkodzeń wzrastają amplitudy drgań po prawej stronie odbicia rzędu 36 (krzywa żółta). Rząd 33 wykazuje również wysoki poziom drgań - rys. 22 .

\section{Order 108}

Drgania dla rzędów harmonicznych lustrzanych do 108 Ord wzrastają w miarę oddalania się od centralnego rzędu harmonicznego - rys. 23.

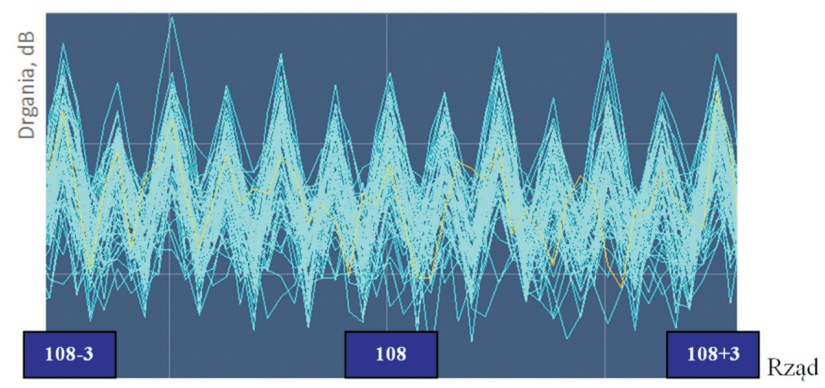

Fig. 23. Harmonic order 108 for the wheel with the chipped tooth Rys. 23. Rzad harmoniczny 108 dla koła z uszkodzonym zębem (drgania - vibrations, rzą-order)

Order 162

Wokół rzędu harmonicznego 162 obserwowano brak symetrii drgań - rys. 24. Rzędy harmoniczne lustrzane są trudne do zdefiniowania w wyniku wysokich amplitud drgań dla rzędu 161 . 


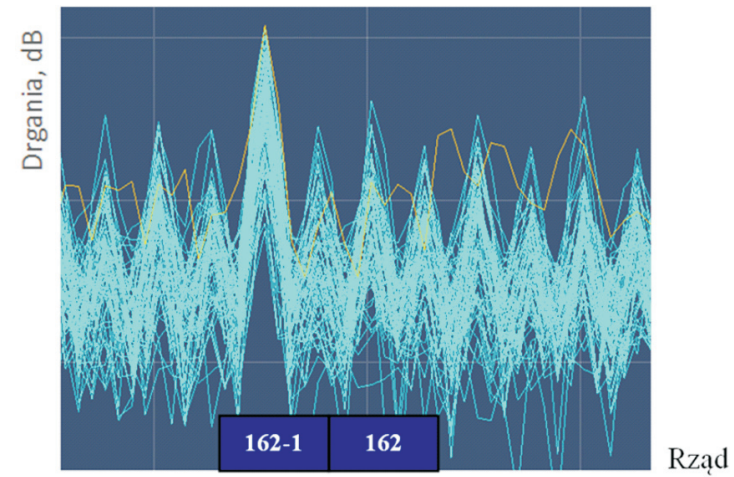

Fig. 24. Harmonic order 162 - teeth damaged with a disc grinder Rys. 24. Rząd harmoniczny162 - zęby uszkodzone szlifierka kątowa (drgania-vibrations, rzad-order)

For the limits curve and the curve of average values of harmonic orders, the vibrations of the wheel with the teeth damaged with a disc grinder are much higher compared to the rest of the investigated cases. These differences are much smaller in the graph representing the maximum values of the vibrations amplitudes of the harmonic orders. The analysis of the three results above indicates that distinguishing the rest of the anomalies is most conspicuous in the graph representing the average values of the order when divided into classes.

The limits curve and the curve of the maximum values of the orders shows a significant growth of the vibrations amplitudes for gear sets with a toothed wheel damaged with a disc grinder, yet, despite severe damage, they are not visible in the entire range from 0 to 200 Ord. For the order curve $2 / 3$ of its area is above the limit and for the curve of maximum orders, there are portions where the curves cross with the curves of other types of damage (less impact on the engine noise level). Only the average value of the orders divided into classes has a significant difference from the others in the results for the 'disc grinder' type of damage and the difference is a minimum of $5 \mathrm{~dB}$ in the entire range from 0 to 200 Ord.

2. For the basic orders (54 and harmonics 108 and 162) the vibrations should increase with the progressing damage. An exact reflection of the above statement is presented by the order that is the most important one for the investigated gear set i.e.: order 54. Further damage results in a growth of the vibrations amplitudes by 2 $\mathrm{dB}$ and for the disc grinder type of damage by $4 \mathrm{~dB}$. For the harmonic orders, the vibrations of the wheel with the teeth damaged with a disc grinder are clearly higher than the rest of the investigated, less severely damaged wheels.

3. The usefulness of image orders in vibroacoustic diagnostics has not been fully defined. The presence of high vibrations amplitudes for order 161 (next to II harmonic of order 54) for all tested engines and the increased value of the vibrations for order 81 for the wheel with the chipped tooth are worth noting and are to undergo further analysis.

\section{Order 27}

Drgania wokół rzędu harmonicznego 27 zachowują się prawidłowo - rys. 25.

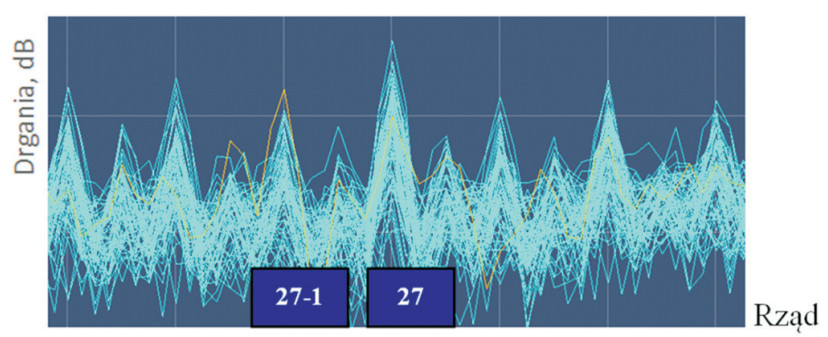

Fig. 25. Harmonic order 27 - wheel with four teeth removed Rys. 25. Rząd harmoniczny 27 - koło bez czterech zębów (drganiavibrations, rząd-order)

\section{Podsumowanie}

1. W pracy porównano skuteczność diagnostyczną trzech analizowanych krzywych drgań:

- krzywej limitu (cały zakres rzędów składowych harmonicznych);

- krzywej maksymalnej wartości amplitudy drgań dla grupy wybranych rzędów harmonicznych (podział na tzw. klasy);

- średnie wartości rzędów harmonicznej w grupie (podział na klasy).

Dla krzywej limitów oraz średnich wartości rzędów harmonicznych drgania koła z zębami uszkodzonymi szlifierką kątową są znacznie większe od pozostałych badanych przypadków uszkodzeń. Na wykresie maksymalnych wartości amplitud drgań rzędów harmonicznych te różnice są znacznie mniejsze. Analiza trzech powyższych wyników badań wskazuje, że wyodrębnienie pozostałych anomalii zębów jest najbardziej widoczne na wykresie średnich wartości rzędów przy podziale na klasy.

Krzywa limitów oraz maksymalnych wartości rzędów pokazuje znaczny wzrost amplitud drgań dla przekładni z uszkodzonym kołem zębatym za pomocą szlifierki kątowej, ale mimo znacznych uszkodzeń nie są one widoczne na całym przedziale od 0 do 200 Ord. Dla krzywej rzędów 2/3 jej obszaru jest powyżej limitu, a dla krzywej maksymalnych rzędów są fragmenty przecinania się z krzywymi z innymi uszkodzeniami (wpływającymi w mniejszym stopniu na głośność silnika). Tylko średnia wartość rzędów z podziałami na klasy ukazuje znaczącą różnicę w wynikach dla uszkodzeń zębów szlifierką kątową od pozostałych, a ich różnica jest w wielkości min $5 \mathrm{~dB}$ w całym przedziale od 0 do 200 Ord.

2. Dla rzędów podstawowych (54 oraz harmoniczne 108 i 162) wraz ze wzrostem uszkodzeń zębów powinny wzrastać drgania. Dokładne odzwierciedlenie powyższej tezy przedstawia rząd najważniejszy dla badanej przekładnirząd 54. Kolejne uszkodzenia powodują wzrost amplitud drgań o $2 \mathrm{~dB}$, a dla uszkodzenia szlifierską aż o $4 \mathrm{~dB}$. Dla rzędów harmonicznych drgania kół z uszkodzonymi zębami szlifierką są wyraźnie wyższe od pozostałych kół z mniejszymi wadami.

3. Przydatność rzędów lustrzanych w diagnostyce wibroakustycznej nie została do końca zdefiniowana. Na uwagę 
4. The increase of vibrations between the case when the teeth are damaged with a disc grinder and the cases of other types of damage:

a) for the limits curve by $7 \mathrm{~dB}$ on average,

b) for the maximum values (of the class) by $5 \mathrm{~dB}$ on average,

c) for the average values (of the class) by $8 \mathrm{~dB}$ on average,

d) for the basic orders by $4 \mathrm{~dB}$,

e) for new orders $0 \mathrm{~dB}$ (comparable results),

f) for image orders $0 \mathrm{~dB}$ (comparable results).

5. The analysis of the average values of the vibrations amplitude in groups of orders of harmonic components (division of the entire range of harmonic orders into classes) is the most efficient method of diagnosing types of damage investigated in the paper.

6. The examples of the solutions using vibroacoustic engine measurements in the cold test presented in the paper indicate a possibility of their use to assess engine technical condition. zasługuje obecność dużych amplitud drgań dla rzędu 161 (obok II harmonicznej rzędu 54) dla wszystkich testowanych silników oraz podwyższona wartość drgań rzędu 81 dla koła z uszkodzonym zębem, które będą w dalszym ciągu analizowane.

4. Wzrost drgań między uszkodzeniami zębów szlifierką kątową a pozostałymi uszkodzeniami zębów:
a) dla krzywej limitów średnio o $7 \mathrm{~dB}$,
b) dla maksymalnych wartości (klasy) średnio o $5 \mathrm{~dB}$,
c) dla średnich wartości (klasy) średnio o $8 \mathrm{~dB}$,
d) dla rzędów podstawowych o $4 \mathrm{~dB}$,
e) dla nowych rzędów $0 \mathrm{~dB}$ (wyniki porównywalne),
f) dla rzędów lustrzanych $0 \mathrm{~dB}$ (wyniki porównywalne).

5. Analiza średnich wartości amplitudy drgań w grupach rzędów składowych harmonicznych (podział całego zakresu rzędów harmonicznych na tzw. klasy) jest najskuteczniejszą metodą diagnostyki dla uszkodzeń badanych w pracy.

6. Przedstawione w artykule przykłady konkretnych rozwiązań wykorzystujących wibroakustyczne pomiary silnika podczas testu zimnego wskazują na możliwości wykorzystania tych metod do oceny stanu jakościowego silnika.

\section{Bibliography/Literatura}

[1] Bartelmus W., Zimroz R.: Diagnozowanie stanu technicznego przekładni zębatych pracujących w zmiennych warunkach obciążenia z wykorzystaniem badań eksperymentalnych i symulacji komputerowej, Prace Naukowe Instytutu Górnictwa Politechniki Wrocławskiej 131/2010, s. 15-23.

[2] Czech P.: Klasyfikator lokalnych uszkodzeń zębów kół przekładni, wykorzystujący sieci neuronowe MLP oraz ciągłą transformatę falkową, Problemy Eksploatacji 4/2007, s. 6181.

[3] Reruń G.: Wpływ wybranych czynników konstrukcyjnych i eksploatacyjnych na wibroakustyczność przekładni zębatej, Zeszyty Naukowe Politechniki Śląskiej - Transport, nr 77/2012, s. 61-68.

[4] Janczewski Ł.: Diagnostyka uszkodzeń wybranych zespołów silnika o zapłonie samoczynnym podczas testu zimnego (analiza wibroakustyczna), ATH w Bielsku-Białej, praca doktorska, 2013.

[5] Janczewski Ł., Nowakowski J.: Vibroacoustic diagnosis of the internal combustion diesel engine at the end of assembly Line, Combustion Engines 3/2013, s. 936-943.

[6] Erik D.S. Munck, Ken R. Fyfe: Computed order tracking applied to vibration analysis of rotating machinery, University of Alberta 1994.

Zdzisław Stelmasiak, DSc., DEng. - Professor in the Faculty of Mechanical Engineering at University of Bielsko-Biala.

Dr hab. inż. Zdzisław Stelmasiak, prof. ATH - profesor na Wydziale Budowy Maszyn i Informatyki Akademii Techniczno-Humanistycznej w BielskuBiatej.

e-mail: zstelmasiak@ath.bielsko.pl

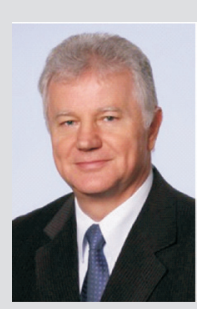

[7] Wang K.S.: Approaches to the improvement of order tracking techniques for vibration based diagnostics in rotating machines, University of Pretoria 2010.

[8] Netter K.: Walcowe koła zębate. Wiadomości podstawowe, Politechnika Poznańska Instytut Technologii Mechanicznej, KN - ver. 6.10.2008, Poznań 2008, s. 7.

[9] Brüel \& Kjær: Wibracje i wstrząsy, broszura, Nærum, Dania 1984.

[10] Madej H.: Wykorzystanie metod wibroakustycznych w diagnostyce silników spalinowych, Zeszyty Naukowe Politechniki Śląskiej - Transport, nr 65/2009, s. 45-50.

[11] Mączak J.: Wykorzystanie lokalnej płaszczyzny przyporu w wykrywaniu błędów wykonania i montażu przekładni zębatych, Diagnostyka 4/2011, s. 47-52.

[12] Stelmasiak Z., Rudnicki M.: Wykorzystanie sygnałów wibroakustycznych w diagnostyce silników samochodowych w teście zimnym. Logistyka 3/2014.

[13] www.ec-diagnostics.pl

[14] www.pcb.energocontrol.pl

[15] www.bruel.com.pl

[16] www.adm-messtechnik.de

[17] www.netter.strefa.pl

Mariusz Rudnicki, MEng. - doctoral student at the Faculty of Machine Design and Information Technology, University of Bielsko-Biała.

Mgr inż. Mariusz Rudnicki-doktorant na Wydziale Budowy Maszyn i Informatyki Akademii Techniczno-Humanistycznej w Bielsku-Biatej. e-mail: mariusz.rudnicki@fiat.com 